\title{
Peramalan Jumlah Kasus COVID-19 di Provinsi Sulawesi Barat Menggunakan Model Hybrid ARIMA Backpropagation
}

\author{
Maryam $^{* 1}$, Rahmawati ${ }^{2}$, Asrirawan ${ }^{3}$ \\ ${ }^{1,2}$ Program Studi Matematika,Universitas Sulawesi Barat, Indonesia \\ ${ }^{3}$ Program Studi Statistika, Universitas Sulawesi Barat, Indonesia \\ e-mail: ${ }^{* 1}$ ruslimarsia23@gmail.com, ${ }^{2}$ rahma@unsulbar.ac.id, ${ }^{3}$ asrirawan@ unsulbar.ac.id
}

\begin{abstract}
Abstrak
COVID-19 (Coronavirus Disease 2019) adalah virus jenis baru yang telah menjadi pandemik. Virus ini harus diwaspadai karena penularannya yang relatif cepat yang memberikan dampak secara global pada semua sektor kehidupan masyarakat termasuk di Provinsi Sulawesi Barat. Pertambahan kasus COVID-19 di Provinsi Sulawesi Barat mengalami perubahan data setiap bulanya. Hal ini mengindikasikan data memiliki pola linier dan nonlinier. Sehingga penelitian ini meramalkan jumlah kasus positif COVID-19 di Provinsi Sulawesi Barat kedepannya dengan menerapkan model Hybrid ARIMA backpropagation yang diperkenalkan sebagai metode gabungan linear dan nonlinear. Peramalan ini dilakukan dengan bantuan software $R$ dan Matlab menggunakan data sebanyak 337 hari dengan pembagian data sebanyak tiga kelompok data training yaitu $80 \%$, 70\% dan 60\%. Beberapa tahap yang digunakan dalam peramalan jumlah kasus COVID-19 yaitu menganalisis data dengan menggunakan metode ARIMA. Kemudian melakukan peramalan residual dari model ARIMA tersebut dengan menggunakan metode Backpropagation. Dari hasil analisis model terbaik dipilih berdasarkan nilai MSE diperoleh model Hybrid ARIMA backpropagation lebih baik dibandingkan model ARIMA untuk meramalkan jumlah kasus COVID-19 di Provinsi Sulawesi Barat jika pembagian data dalam memodelkan yaitu training 60\% dengan MSE ARIMA sebesar 993,35 dan MSE Hybrid ARIMA Backpropagation sebesar 866,34 dengan model Hybrid ARIMA (2,1,1) BP dengan struktur jaringan 7-7-1.
\end{abstract}

Kata Kunci: Peramalan, ARIMA, Backpropagation, COVID-19

\section{PENDAHULUAN}

Corona Virus Disease 2019 atau COVID-19 pertama kali diketahui pada akhir tahun 2019 di Wuhan, China. Virus ini menyerang sistem pernapasan dengan gejala seperti pneumonia (Albana et al., 2020). Mudahnya penyebaran virus ini mengakibatkan tingginya jumlah korban yang positif terjangkit, oleh karena itu virus ini telah ditetapkan sebagai global pandemi oleh World Health Organization (WHO) (Kemenkes RI, 2021).

Pemerintah telah mengeluarkan berbagai kebijakan yang bertujuan menekan jumlah kasus korban virus ini, salah satunya dengan melakukan pembelajaran secara daring, pengurangan jam kerja, PSBB (pembatasan sosial berskala besar), dan lain-lain. Salah satu upaya yang dapat dilakukan dengan melakukan pemodelan prediksi atau peramalan jumlah kasus positif COVID-19. Model prediksi dapat digunakan sebagai proyeksi dan optimisasi bagi pemerintah untuk mengambil kebijakan dan mengevaluasi kebijakan yang ada.

Pada penelitian ini dilakukan kombinasi dari dua metode tunggal. Adapun dua metode tunggal yang akan dikombinasikan adalah metode ARIMA (Autoregressive Integrated Moving Average) dan metode Jaringan syaraf tiruan (Artificial Neural Network) dengan menggunakan algoritma backpropagation. Peramalan menggunakan model ARIMA mengasumsikan data yang digunakan berhubungan secara linier (Purba, 2016) . Berbeda dengan ARIMA, model jaringan syaraf tiruan (JST) merupakan metode peramalan yang dapat digunakan untuk memprediksi time series nonlinear, selain itu stasioneritas dari data juga tidak dihiraukan (Munarsih, 2011). Model dari JST yang sering diterapkan dalam bidang peramalan adalah backpropagation. Zhang memperkenalkan peramalan runtun waktu menggunakan model hybrid ARIMA backpropagation (BP). Model hybrid ARIMA BP dapat mengatasi data yang berpola campuran linier dan nonlinier (Janah et al., 2014).

Beberapa penelitian sebelumnya telah dilakukan dalam rangka peramalan jumlah pada kasus COVID19 yaitu Peramalan Penyebaran Jumlah Kasus Virus COVID-19 Provinsi Jawa Tengah dengan Metode Arima (Rachmawati dan Miasary 2021), dimana peneliti ini bertujuan untuk menganalisa perkembangan pandemi di wilayah Indonesia khususnya provinsi Jawa Tengah.. Penelitian selanjutnya yaitu Peramalan Kasus Positif

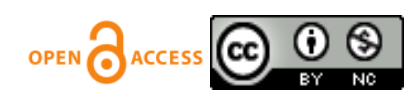


COVID-19 di Indonesia Menggunakan LSTM (Long Short Term Memory) (Pakan, 2020). Dalam penelitian ini dikembangkan metode prediksi time series untuk memperkirakan jumlah kasus penyebaran COVID-19 dengan jaringan saraf tiruan utamanya LSTM dan lebih baik kinerjanya dibandingkan dari algoritma ERNN dalam memprediksi jumlah kasus penyebaran pandemi ini.

Berdasarkan uraian yang telah disampaikan, peneliti melakukan penelitian dengan melakukan peramalan jumlah kasus COVID-19 di Provinsi Sulawesi Barat menggunakan Model Hybrid ARIMA backpropagation". Keterbaruan dari penelitian dari dari komparasi dua model yang terapkan. Penelitian dilakukan dengan tujuan untuk memperoleh model dalam memprediksi penambahan kasus COVID-19 di Sulawesi Barat serta membandingkan model ARIMA dengan model Hybrid ARIMA backpropagation dalam peramalan COVID-19 di Provinsi Sulawesi Barat.

\section{METODE PENELITIAN}

Jenis penelitian adalah penelitian kuantitatif, yaitu penelitian yang menggunakan data berupa angka sebagai alat menganalisis keterangan yang ingin diketahui, serta kajian pustaka yang memanfaatkan sumber kepustakaan yang terdapat di perpustakaan, internet dan buku-buku yang berkaitan dengan metode ARIMA dan Jaringan Syaraf Tiruan ackpropagation. Metode yang digunakan dimulai dari studi literatur, mencari referensi, pencarian data, pengolahan data, analisis data dan mendapatkan hasil pengambilan keputusan dalam Model Hybrid ARIMA backpropagation terbaik. Beberapa tahapan penelitian adalah mengkaji ulang terkait ARIMA, JST, dan hybrid serta menyusun prosedur hybrid ARIMA backpropagation yang meliputi tahap pemodelan ARIMA dan JST algoritma backpropagation. Variabel penelitian yang digunakan yaitu data harian kasus positif COVID-19 pada bulan Maret 2020 - Februari 2021 dan membagi data menjadi dua kelompok yaitu data training dan data testing. Beberapa komposisi data training dan data testing yang digunakan dalam penelitian ini adalah $80 \%$ dan $20 \%, 70 \%$ dan $30 \%$, serta $60 \%$ dan $40 \%$. Residu model ARIMA terbaik digunakan sebagai masukkan untuk algoritma backpropagation dengan menggunakan fungsi aktivasi sigmoid biner, menentukan arsitektur jaringan dengan pelatihan menggunakan program R, metode optimasi LevenbergMarquardt, dan pengujian iterasi maksimum sebanyak 10000 iterasi pada proses pelatihan (data training) dan melakukan pengujian jaringan dengan memilih jaringan optimum yang memiliki nilai MSE terkecil dari proses pengujian (data testing). Hasil peramalan diperoleh dengan menggabungkan hasil peramalan menggunakan metode ARIMA dan hasil peramalan residual menggunakan metode jaringan syaraf tiruan algoritma backpropagation sehingga terbentuk Model Hybrid ARIMA backpropagation.

\subsection{Metode Analisis Data}

\section{1.1 Peramalan}

Peramalan merupakan suatu teknik untuk memperkirakan suatu nilai pada masa yang akan datang dengan memperhatikan data masa lalu maupun data saat ini. Model deret waktu berupaya untuk meramalkan kondisi masa yang akan datang dengan menggunakan data historis dan mengekstrapolasikan pola tersebut ke masa depan. (Aswi \& Sukarna, 2006).

\subsubsection{ARIMA (Autoregressive integrated Moving Average)}

Model ARIMA merupakan perluasan dari model ARMA dengan penambahan parameter d yang merupakan jumlah proses differencing. Secara umum, model ARIMA ini dituliskan dengan notasi ARIMA ( $\mathrm{p}$, d, q). Model-model yang mungkin dihasilkan dari pengidentifikasian data deret waktu dapat berupa model autoregressive (AR), integrated (I) dan moving average (MA) atau kombinasi dari dua komponen model (ARI, IMA, ARMA) atau kombinasi dari tiga komponen model. Nilai konstanta p dan q biasanya didapatkan dari estimasi gambar ACF dan PACF. Sedangkan untuk nilai d umumnya didapatkan dari melakukan trial error terhadap nilai $\mathrm{p}$ dan $\mathrm{q}$ yang sudah didapatkan. Secara umum persamaan ARIMA $(\mathrm{p}, \mathrm{d}, \mathrm{q})$ sebagai berikut:

$\phi_{p}(B)(I-B)^{d} Z_{t}=\theta_{q}(B)_{a_{t}}$

Keterangan:

$\mathrm{p}$ adalah orde AR 
$\mathrm{d}$ adalah orde differencing non-musiman

$\mathrm{q}$ adalah orde MA

$\phi_{p}(B)=\left(1-\phi_{1} B-\phi_{2} B^{2}-\ldots-\phi_{p} B^{p}\right) t$

$\theta_{q}(B)=\left(1-\theta_{1} B-\theta_{2} B^{2}-\ldots-\theta_{q} B^{q}\right)$

$\phi_{1}, \phi_{2}, \phi_{3}, \ldots, \phi_{p}$ adalah koefisien orde $\mathrm{p}$

$\theta_{1}, \theta_{2}, \theta_{3}, \ldots, \theta_{q}$ adalah koefisien orde $\mathrm{q}$

$(1-\mathrm{B})^{d}$ adalah orde differencing non - musiman

\subsubsection{Backpropagation}

Metode pelatihan backpropagation atau disebut dengan generalized delta rule adalah sebuah metode pelatihan terawasi untuk meminimumkan error pada output dalam sebuah jaringan. Menurut (Fausett, 1994), terdapat tiga tahapan utama dari algoritma backpropagation yaitu tahap feedforward pada pola pelatihan input, tahap perhitungan dan backpropagation dari nilai error, dan yang terakhir adalah tahap penyesuaian bobot. Setelah pelatihan telah selesai dilakukan dan didapat jaringan optimum, pengujian jaringan akan dilakukan hanya menggunakan komputasi pada tahap feedforward seperti sebelumnya.

\subsubsection{Metode Hybrid ARIMA Backpropagation}

Dalam peramalan deret waktu, telah dikembangkan metode gabungan dari dua metode tunggal yang disebut dengan metode Hybrid. Pengembangan metode Hybrid dilakukan dengan beberapa alasan sebagai berikut (Zhang, 2003):

- Meningkatkan efisiensi dalam tahapan analisis peramalan deret waktu. Sulitnya menentukan apakah deret waktu mengandung pola linier maupun nonlinier membuat peneliti menggunakan lebih dari satu metode saja untuk dilakukan perbandingan. Dengan melakukan kombinasi Hybrid, permasalahan seleksi model dapat diminimalisir.

- Sangat jarang terdapat kasus time series yang murni linier maupun nonlinier.

Pola data lebih sering mengandung campuran keduanya. Jika kasus seperti ini yang dihadapi, maka metode tunggal dinilai kurang efektif karena tidak dapat menangkap pola campuran.

- Tidak ada suatu metode tunggal yang terbaik dalam setiap situasi. Hal ini dikarenakan permasalahan yang kompleks dalam kasus nyata sehingga sebuah metode tunggal tidak dapat menangkap berbagai macam pola yang terkandung dalam data dengan baik.

Model Hybrid ARIMA backpropagation merupakan gabungan model ARIMA dan backpropagation. Runtun waktu yang tersusun terdiri dari struktur autokorelasi linear dan nonlinear, sehingga dapat direpresentasikan dalam bentuk

$y_{t}=L_{t}+N_{t}$

dengan $L_{t}$ merupakan komponen linear dan $N_{t}$ merupakan komponen nonlinear. ARIMA digunakan untuk memodelkan komponen linear, kemudian residu dari komponen linear hanya berisi hubungan nonlinear. Memodelkan residu menggunakan JST dapat mengatasi komponen nonlinear dalam data. Model residunya dapat ditulis dalam bentuk

$e_{t}=f\left(e_{t-1}, e_{t-2}, \ldots, e_{t-n}\right)+\varepsilon_{t}$

dengan $e_{t}$ merupakan residu model ARIMA, $f$ merupakan fungsi nonlinear yang ditentukan menggunakan backpropagation dan $\varepsilon_{t}$ merupakan eror random. Persamaan (3) dapat ditulis dalam bentuk:

$e_{t}=\alpha_{0}+\sum_{j=1}^{q} \alpha_{j} g\left(\beta_{0 j}+\sum_{i=1}^{p} \beta_{i j} e_{t-1}\right)+\varepsilon_{t}$ 
dengan $g$ merupakan fungsi aktivasi yang digunakan dalam lapisan tersembunyi yaitu log sigmoid. Dalam penyusunan struktur jaringan digunakan transformasi pada preprocessing, yaitu:

$$
X^{\prime}=\frac{0,8(X-b)}{(a-b)}+0,1
$$

dengan $a$ sebagai nilai tertinggi interval dan $b$ sebagai nilai terendah interval (Janah, et.al, 2014)

\section{HASIL DAN PEMBAHASAN}

Data yang digunakan pada penelitian ini merupakan data harian pertambahan kasus positif COVID-19 di Provinsi Sulawesi Barat pada bulan Maret 2020-Februari 2021. Sebaran data kasus pertambahan jumlah COVID-19 Provinsi Sulawesi Barat digambarkan dalam boxplot pada Gambar 1

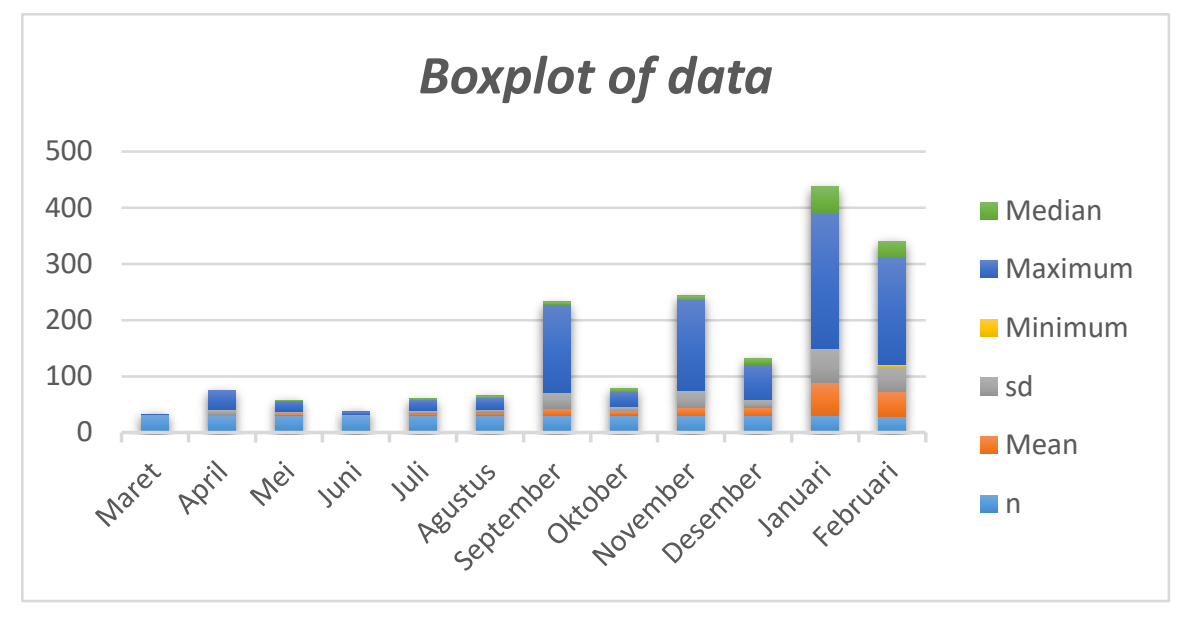

Gambar 1 Boxplot Data Kasus COVID-19 Sulawesi Barat

Berdasarkan boxplot Gambar 1 dapat dilihat bahwa kasus COVID-19 pada bulan Maret 2020 hingga Agustus 2020 masih memiliki jumlah kasus yang bisa dikatakan rendah, kemudian meningkat pada bulan September 2020 sampai bulan Februari 2021. Pada bulan Januari 2021 terjadi peningkatan jumlah kasus positif COVID-19 di Provinsi Sulawesi Barat yang memiliki jumlah maksimum tertinggi. Pada Gambar 4.1 juga terlihat bahwa terdapat data outlier di bulan Januari. Data outlier pada bulan Januari terdapat pada data ke- 327 yaitu pada tanggal 21 Januari 2021.

Keberadaan outlier pada data dapat mengakibatkan pola menjadi tidak linear. Model ARIMA merupakan fungsi linear, sehingga mungkin bukan model terbaik untuk mewakili jumlah kasus COVID-19 di Provinsi Sulawesi Barat. Oleh sebab itu, akan dilakukan penggabungan metode yaitu Hybrid ARIMA backpropagation yang dapat menangkap pola non linier.

\subsection{Peramalan Menggunakan Metode ARIMA}

Peramalan menggunakan metode ARIMA membutuhkan beberapa tahapan, yaitu identifikasi model, estimasi model, tahap penaksiran parameter, dan uji diagnostik model serta kelayakan model. Dalam pengidentifikasian model ARIMA data training diperiksa kestasioneran data runtun waktu terlebih dahulu. Hasil penelitian menunjukkan bahwa data tidak stasioner sehingga perlu dilakukan pembedaan (differencing). Kemudian, dilakukan uji akar-akar unit Augmented Dickey-Fuller pada data hasil perbedaan orde satu. Uji ADF memberikan hasil bahwa data perbedaan orde satu sudah stasioner. Selanjutnya, model ARIMA sementara dapat diidentifikasi dengan menggunakan plot ACF dan PACF sebagai acuannya. Diperoleh model awal yaitu ARIMA $(0,1,1)$, ARIMA $(1,1,0)$, ARIMA $(1,1,1)$, ARIMA $(2,1,0)$, dan ARIMA $(2,1,1)$. Selanjutnya, tahap penaksiran parameter, dan uji diagnostik model terpilih model ARIMA $(1,1,1)$ dan ARIMA $(2,1,1)$ yang memenuhi kriteria. Kemudian, akan dilakukan pemilihan model terbaik menggunakan data testing ditinjau dengan nilai MSE, RMSE, dan MAE terkecil. Berdasarkan perhitungan nilai MSE, RMSE 
dan MAE Model ARIMA $(2,1,1)$ yang memiliki nilai MSE, RMSE, dan MAE terkecil dan terdapat pada jenis data testing $40 \%$ dari jenis data yang lain. Hal ini dapat kita simpulkan kriteria kebaikan model mengacu pada banyaknya data yang digunakan dalam peramalan COVID-19 ini. Hal ini disebabkan pola penyebaran COVID19 yang cepat dimana masa inkubasi diperkirakan antara 1-14 hari menurut standar WHO dan 2-14 hari oleh Centers for Disease Control and Prevention (CDC). Model ARIMA $(2,1,1)$ dapat ditulis sebagai:

$$
Z_{t}=\left(\phi_{1}+1\right) Z_{t-1}+\left(\phi_{2}-\phi_{1}\right) Z_{t-2}-\phi_{2} Z_{t-3}-\theta_{1} a_{t-1}+a_{t}
$$

dengan taksiran parameter masing-masing training dan testing

1. Training $80 \%$ dan testing $20 \%$

$$
Z_{t}=(0,0033+1) Z_{t-1}+(0,1916-0,0033) Z_{t-2}-0,1916 Z_{t-3}+0,9721 a_{t-1}+a_{t}
$$

2. Training $70 \%$ dan testing $30 \%$

$$
Z_{t}=(-0,0034+1) Z_{t-1}+(0,1908+o, 0034) Z_{t-2}-0,1908 Z_{t-3}+0,9696 a_{t-1}+a_{t}
$$

3. Training $60 \%$ dan testing $40 \%$

$$
Z_{t}=(-0,0227+1) Z_{t-1}+(0,1944+0,0227) Z_{t-2}-0,1944 Z_{t-3}+0,9537 a_{t-1}+a_{t}
$$

Persamaan (5) Model ARIMA diatas, dapat diartikan bahwa peramalan jumlah kasus COVID-19 di Provinsi Sulawesi Barat dipengaruhi oleh jumlah kasus COVID-19 pada tiga periode sebelumnya dan kesalahan peramalan jumlah kasus COVID pada satu periode sebelumnya.

3.2 Peramalan Menggunakan Metode Hybrid ARIMA Backpropagation

Pada penelitian ini, data yang digunakan untuk membangun model jaringan Hybrid ARIMA backpropagation adalah data hasil residual masing-masing data training $80 \%, 70 \%$ dan $60 \%$ pada model terbaik ARIMA. Tahap-tahap yang dilakukan dalam pemodelan Hybrid ARIMA backpropagation meliputi pelatihan dan pengujian jaringan serta memilih struktur jaringan optimum.

Penelitian ini, menggunakan fungsi aktivasi sigmoid biner di mana fungsi ini bernilai antara 0 s.d 1. Oleh sebab itu, data harian pertambahan kasus COVID-19 perlu dinormalisasi terlebih dahulu ke dalam range 0,1 s.d 0,9 menggunakan persamaan (4). Jumlah lapisan input jumlah neuron yang ditetapkan adalah 7 neuron mengacu pada jumlah hari dalam 1 minggu.

Pelatihan menggunakan algoritma backpropagation dengan metode optimasi LevenbergMarquardt (trainlm) dan fungsi aktivasi log sigmoid, dengan kriteria jaringan yang digunakan untuk proses pengujian yaitu iterasi maksimum sebanyak 10000 iterasi pada proses pelatihan. Hasil pelatihan untuk data training ditampilkan pada tabel 1 sebagai berikut:

Tabel 1 Hasil Pelatihan MSE Terkecil

\begin{tabular}{|c|c|c|c|}
\hline Struktur & $\begin{array}{c}\text { MSE } \\
\text { (Training 80\%) }\end{array}$ & $\begin{array}{c}\text { MSE } \\
\text { (Training 70\%) }\end{array}$ & $\begin{array}{c}\text { MSE } \\
\text { (Training 60\%) }\end{array}$ \\
\hline $\mathbf{( 7 - 2 - 1 )}$ & 0.000248 & $2.62 \mathrm{e}-05$ & $3.34 \mathrm{e}-05$ \\
\hline $\mathbf{( 7 - 3 - 1 )}$ & $9.52 \mathrm{e}-05$ & $3.15 \mathrm{e}-09$ & $5.98 \mathrm{e}-10$ \\
\hline $\mathbf{( 7 - 4 - 1 )}$ & $7.57 \mathrm{e}-06$ & $9.12 \mathrm{e}-11$ & $2.01 \mathrm{e}-12$ \\
\hline $\mathbf{( 7 - 5 - 1 )}$ & $1.03 \mathrm{e}-14$ & $2.50 \mathrm{e}-09$ & $5.25 \mathrm{e}-13$ \\
\hline $\mathbf{( 7 - 6 - 1 )}$ & $8.04 \mathrm{e}-10$ & $1.30 \mathrm{e}-10$ & $2.73 \mathrm{e}-09$ \\
\hline $\mathbf{( 7 - 7 - 1 )}$ & $3.15 \mathrm{e}-10$ & $1.70 \mathrm{e}-10$ & $4.29 \mathrm{e}-11$ \\
\hline $\mathbf{( 7 - 8 - 1 )}$ & $7.85 \mathrm{e}-11$ & $1.03 \mathrm{e}-12$ & $2.95 \mathrm{e}-13$ \\
\hline $\mathbf{( 7 - 9 - 1 )}$ & $2.06 \mathrm{e}-14$ & $7.17 \mathrm{e}-14$ & $7.75 \mathrm{e}-13$ \\
\hline $\mathbf{( 7 - 1 0 - 1 )}$ & $3.55 \mathrm{e}-10$ & $2.33 \mathrm{e}-18$ & $1.59 \mathrm{e}-13$ \\
\hline
\end{tabular}

Berdasarkan tabel 1 diatas, diketahui bahwa semakin banyak hidden layer yang digunakan diperoleh nilai dari MSE cenderung semakin kecil. Nilai MSE yang semakin kecil menunjukkan kebaikan 
https://jurnal.unsulbar.ac.id/index.php/saintifik

model semakin baik. Dalam penelitian ini, menentukan struktur yang baik ditinjau dari kebaikan data yang digunakan. Kebaikan data dapat dlihat pada plot regresi. Nilai $R$ yang mendekati 1 dapat memberikan informasi kecocokan data dengan model semakin baik. Adapun struktur jaringan yang diperoleh yaitu training 80\% [(7-6-1), (7-7-1), (7-8-1), (7-9-1)], training 70\% [(7-2-1), (7-3-1), (7-6-1), (7-7-1), (7-81), (7-9-1)] dan training 60\% [(7-2-1), (7-6-1), (7-7-1), (7-8-1), (7-9-1), (7-10-1)]. Selanjutnya, melakukan pengujian jaringan pada data residual dari data testing ARIMA terbaik. Adapun hasil pengujian akan ditampilkan pada tabel 2.

Tabel 2 Hasil Pengujian Data Testing Jaringan yang Baik

\begin{tabular}{|l|l|l|l|l|l|}
\hline \multicolumn{3}{|l|}{ Testing 40\% } & \multicolumn{1}{l|}{ Testing 30\% } & Testing 20\% \\
\hline Struktur & MSE & Struktur & MSE & Struktur & MSE \\
\hline $\mathbf{7 - 2 - 1}$ & 0,00280 & $\mathbf{7 - 2 - 1}$ & $3.62 \mathrm{e}-14$ & $\mathbf{7 - 6 - 1}$ & $6.43 \mathrm{e}-13$ \\
\hline $\mathbf{7 - 6 - 1}$ & 0,00279 & $\mathbf{7 - 3 - 1}$ & $1.05 \mathrm{e}-13$ & $\mathbf{7 - 7 - 1}$ & $8.09 \mathrm{e}-13$ \\
\hline $\mathbf{7 - 7 - 1}$ & $3.58 \mathrm{e}-19$ & $\mathbf{7 - 6 - 1}$ & $2.89 \mathrm{e}-12$ & $\mathbf{7 - 8 - 1}$ & $9.09 \mathrm{e}-12$ \\
\hline $\mathbf{7 - 8}-1$ & 0,00279 & $\mathbf{7 - 7 - 1}$ & $2.10 \mathrm{e}-14$ & $\mathbf{7 - 9 - 1}$ & $2.04 \mathrm{e}-09$ \\
\hline $\mathbf{7 - 9 - 1}$ & $2.47 \mathrm{e}-11$ & $\mathbf{7 - 8 - 1}$ & $1.39 \mathrm{e}-10$ & & \\
\hline $\mathbf{7 - 1 0 - 1}$ & $2.10 \mathrm{e}-12$ & $\mathbf{7 - 9 - 1}$ & $5.96 \mathrm{e}-14$ & & \\
\hline
\end{tabular}

Berdasarkan informasi dari tabel 2 diketahui dari ketiga pengujian data testing diperoleh masingmasing nilai MSE yang cukup kecil. Jaringan Optimum adalah jaringan yang memiliki nilai MSE terkecil dari proses pengujian, yaitu 3.58e-19 pada testing 40\% dengan struktur [7-7-1], 2.10e-14 pada testing 30\% dengan struktur [7-7-1] serta 6.43e-13 pada testing 20\% dengan struktur [7-6-1] . Gambar 3.

Struktur jaringan 7-7-1 ditunjukkan pada Gambar 2 dan struktur jaringan 7-6-1 ditunjukkan pada

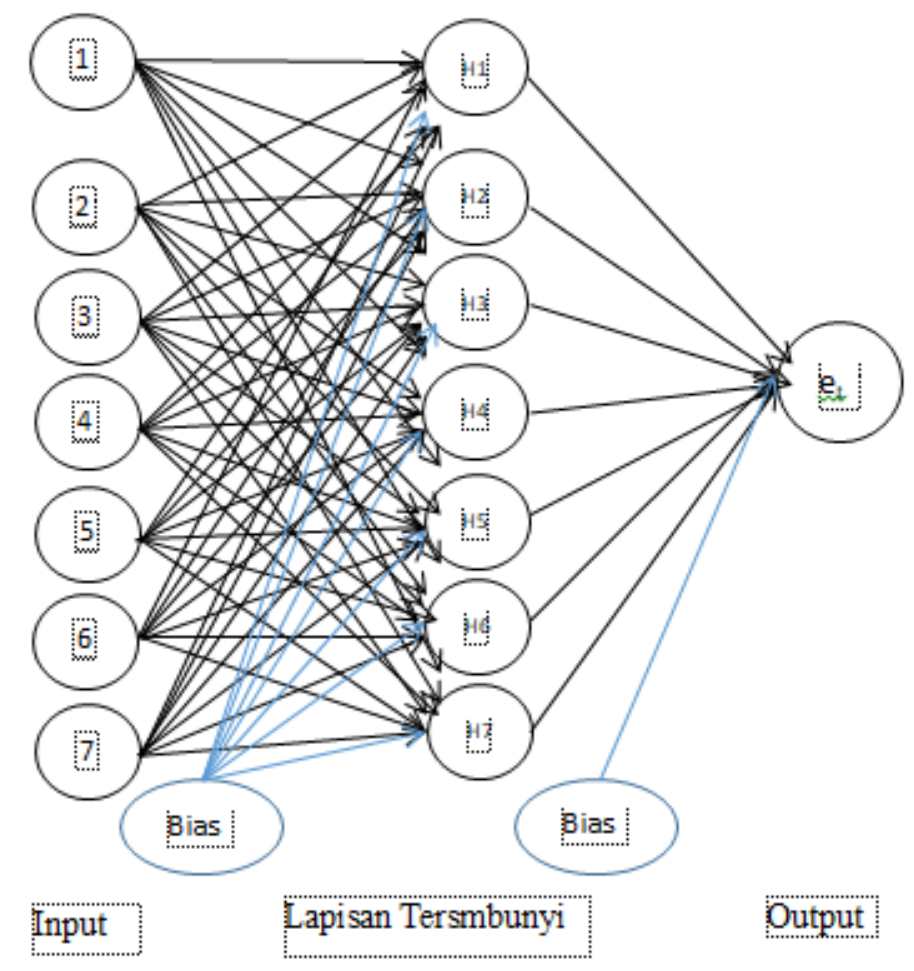

Gambar 2 Struktur Jaringan [7-7-1]

Pembobotan yang digunakan pada struktur jaringan [7-7-1] adalah sebagai berikut: 
https://jurnal.unsulbar.ac.id/index.php/saintifik

$v_{j i}=\left(\begin{array}{ccccccc}1,4944 & 0,22261 & 1,4259 & -2,2046 & 0,73828 & 1,5359 & 1,2608 \\ 1,6204 & 1,8269 & -1,43 & 1,3941 & -1,313 & 0,77797 & 1,1788 \\ -1,6212 & 2,0205 & -0,34004 & 1,8862 & 0,89552 & -0,79492 & -1,3609 \\ 1,5979 & -1,3235 & 1,607 & 0,6909 & -1,8097 & 1,7403 & -0,03956 \\ 0,60226 & 2,1413 & 1,3296 & 1,1728 & -1,015 & -2,1184 & -0,24759 \\ -1,5932 & 1,8097 & 1,819 & 0,96247 & -1,7965 & -0,24249 & 0,5792 \\ -1,4821 & -0,097857 & 1,0421 & -0,72115 & -2,6957 & -0,79254 & 1,4009\end{array}\right)$

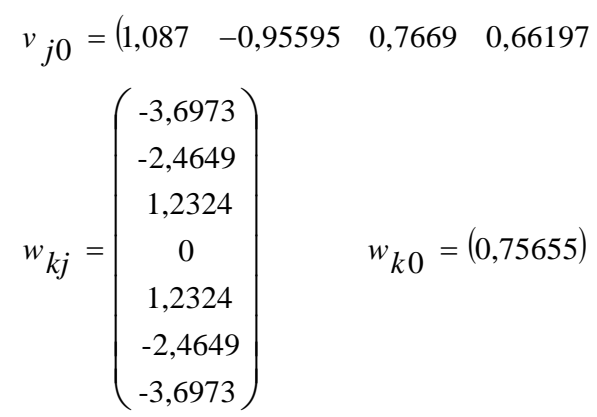

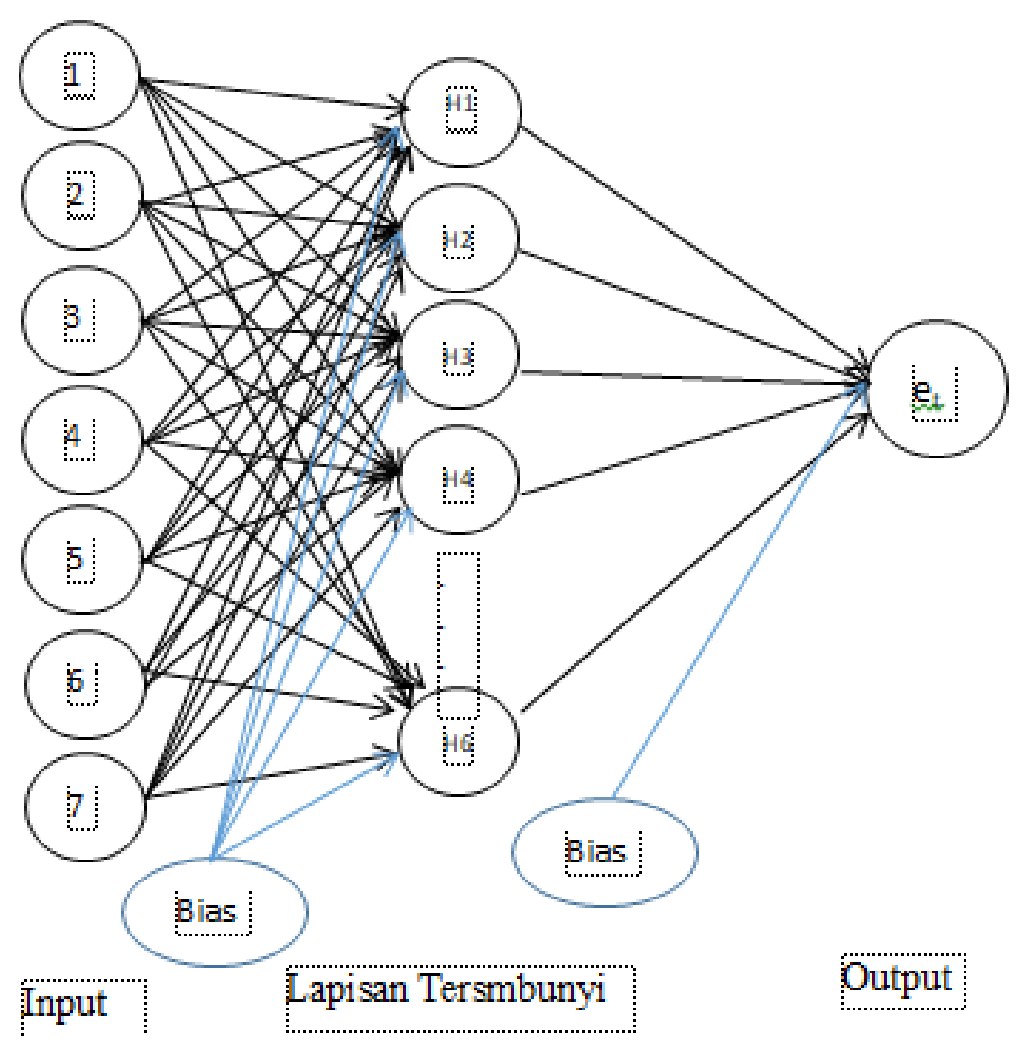

Gambar 3 Struktur Jaringan [7-6-1] 
https://jurnal.unsulbar.ac.id/index.php/saintifik

Pembobotan yang digunakan pada struktur jaringan [7-6-1] adalah sebagai berikut:

$$
\begin{aligned}
& v_{j i}=\left(\begin{array}{ccccccc}
0,25563 & 1,7528 & -1,6543 & 1,4323 & 0,32779 & -2,1113 & -0,76816 \\
0,75449 & 2,0039 & -0,70728 & -0,83924 & -1,3275 & 1,3338 & -1,9366 \\
-2,145 & 2,3366 & -1,3728 & -0,012811 & -0,26621 & -0,37566 & -0,96088 \\
2,4232 & -1,3037 & 1,3135 & 1,181 & 1,2961 & -0,37695 & -0,75359 \\
-0,25689 & 0,89706 & -1,1218 & 1,7315 & 1,9907 & -1,9832 & 0,24108 \\
-1,6154 & 0,90165 & 2,1745 & 0,6017 & 1,2122 & 1,7271 & 0,33985
\end{array}\right) \\
& v_{j 0}=\left(\begin{array}{llllll}
-0,53341 & -0,52519 & 0,078684 & 0,80659 & 2,3088 & 1,1385
\end{array}\right) \\
& w_{k j}=\left(\begin{array}{c}
-3,6168 \\
-2,1701 \\
0,72336 \\
0,72336 \\
-2,1701 \\
-3,6168
\end{array}\right) \\
& w_{k 0}=(-1,6388)
\end{aligned}
$$

Dengan $v_{j i}$ merupakan bobot yang menghubungkan setiap unit input ke hidden layer memiliki bias $v_{j 0}$, dan $w_{k j}$ merupakan bobot penghubung setiap unit hidden layer ke output memiliki bias $w_{k 0}$. Model Hybrid ARIMA backpropagation adalah (2,1,1)[7-6-1] untuk data training $80 \%$ dan $(2,1,1)$ [7-7-1] untuk data training $70 \%$ dan training $60 \%$.

Selanjutnya, hasil peramalan ARIMA dan hybrid ARIMA backpropagation dibandingkan dengan data asli atau data testing. Untuk membandingkan hasil ramalan pada model ARIMA dan hybrid ARIMA backpropagation digunakan Mean Square Error (MSE) sebagai kriteria dalam kebaikan model. Perbandingan nilai MSE dari ketiga data training akan ditampilkan pada Tabel 3 sebagai berikut:

Tabel 3 Perbandingan Kebaikan Model ARIMA dan Hybrid ARIMA Backpropagation

\begin{tabular}{|c|c|c|c|}
\hline Data & ARIMA & $\begin{array}{c}\text { Hybrid ARIMA } \\
\text { Backpropagation }\end{array}$ & Model Terbaik \\
\hline Training $80 \%$ & 1584,020481 & 1660,735845 & ARIMA \\
\hline Training 70\% & 88,93580466 & 154,8571087 & ARIMA \\
\hline Training 60\% & 993,3504203 & 866,341565 & $\begin{array}{c}\text { Hybrid ARIMA } \\
\text { backpropagation }\end{array}$ \\
\hline
\end{tabular}

Berdasarkan nilai MSE yang dihasilkan pada peramalan COVID-19 di Provinsi Sulawesi Barat, diperoleh :

a. Model ARIMA lebih baik dibandingkan model hybrid ARIMA backpropagation untuk meramalkan jumlah kasus COVID-19 di Provinsi Sulawesi barat jika pembagian datanya dalam memodelkan yaitu training $80 \%$ dan training $70 \%$.

b. Model hybrid ARIMA backpropagation lebih baik dibandingkan model ARIMA untuk meramalkan jumlah kasus COVID-19 di Provinsi Sulawesi Barat jika pembagian data dalam memodelkan yaitu training $60 \%$. 
https://jurnal.unsulbar.ac.id/index.php/saintifik

\section{KESIMPULAN}

Model terbaik yang digunakan dalam peramalan jumlah kasus COVID-19 di Provinsi Sulawesi Barat yaitu: training $80 \%$ dan testing $20 \%$ model hybrid ARIMA $(2,1,1)$ BP dengan struktur jaringan 7-6-1, training $70 \%$ dan testing $30 \%$ model hybrid ARIMA $(2,1,1)$ BP dengan struktur jaringan 7-7-1, dan training $60 \%$ dan testing $40 \%$ model hybrid ARIMA $(2,1,1)$ BP dengan struktur jaringan 7-7-1. Model ARIMA lebih baik dibandingkan model hybrid ARIMA backpropagation untuk meramalkan jumlah kasus COVID-19 di Provinsi Sulawesi barat jika pembagian datanya dalam memodelkan yaitu training -80\% dengan MSE ARIMA sebesar 1584,02 banding MSE Hybrid ARIMA backpropagation sebesar 1660,74 dan training 70\% dengan MSE ARIMA sebesar 88,94 banding MSE Hybrid ARIMA backpropagation sebesar 154,85. Serta, model hybrid ARIMA backpropagation lebih baik dibandingkan model ARIMA untuk meramalkan jumlah kasus COVID19 di Provinsi Sulawesi Barat jika pembagian data dalam memodelkan yaitu training 60\% dengan MSE ARIMA sebesar 993,35 banding MSE Hybrid ARIMA backpropagation sebesar 866,34.

\section{DAFTAR PUSTAKA}

Albana, A.S, dan Azhari, S., 2020, Prediksi Penyebaran COVID-19 Kota Surabaya dengan Simulasi Monte Carlo, Journal of Advances in Information and Industrial Technology (JAIIT), No.1, Vol. 2, 36-42.

Aswi, \& Sukarna,. 2006, Analisis Deret waktu Teori dan Aplikasi, Ed. 1, H. Muhammad Arif Tiro: Makassar. Fausett, L. (1994). Fundamentals of Neural networks (Architectures, Algorithms, dan Applications). Upper Saddle River, New Jersey: Prentice.

Janah, S.N., et al, 2014, Penerapan Model Hybrid Arima Backpropagation untuk Peramalan Harga Gabah Indonesia, Media Statistika, No.2, Vol.7, 63-69.

KEMENKES RI, 2021, Situasi Terkini Perkembangan Novel Coronavirus (COVID-19). https://covid19.kemkes.go.id/document/donwload/cover, diakses tgl 8 Februari 2021.

Munarsih E., 2011, Penerapan Model ARIMA Neural Network Hybrid untuk Peramalan Time Series, Thesis, S2 Matematika FMIPA Universitas Gadjah Mada. Yogyakarta.

Pakan, P.D., 2020, Peramalan Kasus Positif di Indonesia Menggunakan LTSM, Jurnal Ilmiah Flash, No.1, Vol.6, 12-15, : https://jurnal.pnk.ac.ad>flash>article

Purba, N., 2016, Pemodelan Data Curah Hujan di Kabupaten Banyuwangi dengan Metode Arima dan Radial Basis Function Neural Network, Skripsi, Fakultas Matematika dan Ilmu Pengetahuan Alam, Institut Teknologi Sepuluh Nopember, Surabaya.

Rachmawati, A.K, dan Miasary, S.D.,2021, Peramalan Penyebaran Jumlah Kasus Virus COVID-19 Provinsi Jawa Tengah dengan Metode Arima, Math Journal, No.1, Vol.6, 11-16

Zhang, G.P., 2003, Time Series Forecasting using a Hybrid ARIMA and Neural Networks Model, Neurocomputing, No. , Vol., 159-175. 